\title{
Managing drought effects on levees in The Netherlands and England
}

\author{
Marcel Bottema ${ }^{1}$, Neil Gunn², Britt van Haastrecht ${ }^{3}$, Bart Vonk ${ }^{1}$ \& Henk van Hemert ${ }^{1,3}$ \\ ${ }^{1}$ Rijkswaterstaat WVL, P.O. Box 2232, 3500 GE Utrecht, The Netherlands \\ ${ }^{2}$ Environment Agency, Addington, Kent, England, ME19 5SH England \\ ${ }^{3}$ STOWA, PO BOx 2180, 3800 CD, Amersfoort, The Netherlands
}

\begin{abstract}
Until quite recently, drought-related risks to levees received relatively little attention in The Netherlands and England, despite the fact that hot and dry summer periods became more common since about 1989, with 2003 producing one of the hottest, driest and sunniest summers measured so far. At the end of that 2003 summer, a dried-out peat levee near the Dutch town of Wilnis suddenly gave way. Especially in the first years that followed, drought effects received more attention in management practices, and a significant amount of research on drought and levees was initiated. Fifteen years later, when attention for drought effects had somewhat declined, another drought struck. This 2018 drought was even more severe than the 2003 one. Probably as a result of the improved levee management practices, no (near-)failures occurred during the 2018 drought. Yet there were several cases of deep cracks and significant damage to grass revetments. In this paper, the 2018 drought effects and drought management practices are described for Dutch and English levees, and some common lessons are drawn.
\end{abstract}

\section{Introduction}

As early as the $16^{\text {th }} / 17^{\text {th }}$ century, when the Dutch were still struggling to prevent frequent flooding of their polders, there seems to have been some awareness of drought risk to peat levees, given for example the construction practices that favoured high phreatic lines in peat levees (Derksen, 2019). Despite this, drought risks do not seem to be a widely recognized risk, given that they are hardly mentioned in a recent levee inventory study covering several countries (EURCOLD, 2019).

Then, during the night of 26 August 2003, at the end of a hot and dry summer, a dried-out peat levee near the Dutch town of Wilnis suddenly gave way. As a result, the residents woke up to find their neighbourhood inundated by a knee-deep layer of water (Van Baars, 2005; CIRIA, 2013). Luckily, the Wilnis failure occurred along a secondary levee along a polder canal. It is also lucky that the Wilnis type of peat levee is mainly restricted to secondary levees with relatively low failing impact. The impact (and loss-of-life-risk) of a primary levee failure, along tidal waters or along major rivers or lakes, would have been much more disastrous, should such a failure occur.

The Wilnis failure triggered several actions to prevent similar failures from happing again. The STOWA Applied Water Research Foundation (www.stowa.nl) has had a key role in these follow-up actions and in producing good practice guidelines (STOWA, 2005) to prevent similar events. One of the first actions was to identify regions and levees with similar vulnerabilities. Next, safety standards for these secondary flood defences were implemented. This implementation also included risk and safety assessment protocols, inspection and management protocols, and warning and management protocols should a drought occur one of the next summer seasons. All in all, the Wilnis failure has been the trigger in developing suitable risk-informed management practices for secondary levees, instead of having those practices for the high-risk primary levees only.

${ }^{\mathrm{a}}$ Corresponding author: $\underline{\text { marcel.bottema@rws.nl }}$

DOI 10.3311/FLOODRisk2020.8.1
The 2003 Wilnis failure has also triggered at least a temporary boost in research regarding both peat levees and the general issue of drought-impact on levees and peat levees. Key results have been included in STOWAguidelines such as (STOWA, 2005)

Some results of the international literature are worth mentioning as well. Vonk (1994) discussed a near-failure case of 1990, where a peat levee suffered severe settlement, deformation and seepage. As an emergency measure, the levee was raised with a $40 \mathrm{~cm}$ thick clay cap, which in that case actually increased the risk of an inner slope failure. Van Baars (2005) attributed the Wilnis failure to horizontal sliding on the peat-sand-layer interface, given the reduced weight of the dry upper layer of peat and increased water infiltration due to peat shrinkage and cracking near the waterline. More recently, it became clear that ancient ditches crossing the levee may also have contributed to its failure (Derksen, 2019). Besides the Wilnis failure, a similar failure during a similarly hot and dry summer occurred in 1947 near the town of Zoetermeer (Van Baars, 2005). Still, only a (very) small fraction of Dutch historical levee failures appears to be drought-induced (Van Baars \& Van Kempen, 2009) .

The results of Dyer et al. (2007) suggest that desiccation fissuring may also contribute to the failure of large(r) clay levees, as for some English coastal levees during the 1953 North Sea Flood Disaster, the largest 20th century flood disaster along the North Sea. Wave overtopping over such a fissured inner slope clay top layer leads to strongly increased infiltration, uplifting clay blocks, and ultimately leading to gradual collapse of the inner slope. This demonstrates that not just secondary but also major, clay(-covered), levees may be vulnerable to weathering and drought effects. In fact, this failure mode may even occur in situations with near-overtopping only (EA, 2007). Dyer et al. (2007) also note that individual cracks can be as deep as 1 metre, but that interconnected cracks down to order $0.5 \mathrm{~m}$ depth are the most critical. The depth to which cracks and weathered clay extend can be 
much deeper near deep-rooted vegetation like trees, and can reach (Van den Akker et al., 2013) of 2 metres and even more (EA, 2007).

In warmer countries, soils can dry out down to even greater depths reaching about 3 metres in the case of France (Boussafir et al., 2019). Vahedifard et al. (2016) reported cracks as deep as $2.7 \mathrm{~m}$ for a levee in Texas, deep enough to be able to trigger geotechnical failure when these cracks result in hydraulic short-circuiting during or shortly after the drought. This would not only be relevant for levees, but even for earthen dams. Besides the risk of levee cracks, they also mention the risks of oxidation of organic subsoil and the related land subsidence (up to $5 \mathrm{~cm}$ per month shrinkage and/or oxidation effect during drought) in the Californian Delta. For natural soils, Morris et al (1992) report observed crack depths in a similar range, that can reach 0.5 to 6 metres, roughly equal to the depth of seasonal moisture change, but sometimes deeper, suggesting that once formed, cracks can be very persistent.

The above suggests that in an international context, drought-related failure risks to levees and probably even to earthen dams cannot be neglected. In fact, Boussafir et al. (2019) report that cracking is observed in $35 \%$ of earthen dams in the French Gers region.

The main reason for revisiting the drought issue in this paper is linked to the fact that compared to 2003, an even more extreme drought occurred in 2018. This raised the question how levees have performed this time, and to what extent levees management practices have improved and payed off. Some preliminary results are already reported by (Bottema et al, 2019). In this paper, some more results are included, and the scope is extended to England where a similar drought occurred in 2018.

In this paper, the hydro-meteorological conditions will be discussed first. Then the effect of the drought on the levees will be discussed from a practitioners (rather than a theoretical) viewpoint, as well as the mitigating measures that were taken. The Dutch and English experiences will be compared, after which some conclusions and general recommendations will be given.

\section{Levees in The Netherlands and England}

Properties of the Dutch and English levee portfolio, and its governance and management are extensively described in (EURCOLD, 2019), so only a brief summary is given here.

In The Netherlands, Flood Risk Management (FRM) relies to a large extent on protection through levees (and dunes and hydraulic works), given the fact that over $60 \%$ of (economic) assets and people are concentrated in floodprone areas. There are over $3000 \mathrm{~km}$ of primary levees along major water systems (tidal waters, large lakes, large rivers; often with the potential of causing significant lifeloss hazard). There are also about $10000 \mathrm{~km}$ of regional/secondary levees along smaller water systems. One third of them $(\sim 3000 \mathrm{~km}$; Van Haastrecht, 2019) is relatively vulnerable to drought as these levees are either built on top of peat subsoil, or actually consist of peat. The latter is either due to peat excavation that took place around those levees or because of the fact those levees are actually built using peat. All in all, at least $20 \%$ of Dutch levees is likely to be vulnerable to drought, and a few percent even very vulnerable. These vulnerable levees are mainly (though not exclusively) concentrated in Central and Northern Holland and Frisia.

Most levees are managed (and often owned) by one of the 21 Water Boards, and some of them by the government agency Rijkswaterstaat. Especially primary levees have a well-established framework of safety standards, with once every 5-12 years an in-depth quantitative safety assessment facilitated by dedicated software and guidelines (Slomp et al., 2016), plus regular (weekly to twice-yearly) as well as intensified inspections. Following these in-depth safety assessments, many primary levees have been rehabilitated in recent decades, or will be in the next decade or so. Since the Wilnis levee failure in 2003, practices for secondary levees (although somewhat less stringent) are quickly catching up with those for primary levees, while intensified inspections for both primary and secondary levees are no longer limited to flood situations, but also applied in the case of drought risk to levees.

According to the Environment Agency, England has slightly over $10000 \mathrm{~km}$ of raised embankments or levees in England alone. No information was readily available on Northern Ireland, Scotland and Wales, but for this paper, these regions are less relevant because the 2018 drought (and its impact) was most pronounced in the south-eastern half of the UK. Fluvial levees can be found in pretty much every English region. Some areas like for example Somerset, Lincolnshire, Kent and East Anglia have 'drained levels' landscape types. These often have land subsidence issues related to drying peat sub-soils, so that to water courses can become high-level carriers over time. Many major levees along major water courses are owned and managed by the Environment Agency. The remaining levees are often managed by regional and local authorities such as Internal Drainage Board and other FRM Authorities.

Levee heights in England are mostly in the range of 16 metres, with typical slope steepnesses in the order of 1:2 to $1: 3 \mathrm{~V}: \mathrm{H}$. Levee construction materials are quite location dependent and often, levees have non-homogeneous cross sections. Sand, silt and clay (in various states of compaction) may all be present. Peaty subsoils occur as well, especially in regions along the English East Coast. However, peat is rarely used for levee construction (Welton, 2018). According to (EA, 2007), about $10 \%$ of the UK levees is vulnerable to drought. In fact, ground shrinkage over the summer regularly affects the south-east of England where there are extensive alluvial clay formations and embankments (EA, 2017).

Safety requirements depend amongst others on costbenefit ratio. They are typically in the range of $1 / 100 \mathrm{yr}$ or $1 / 200 y$ r annual probability, but can actually range from $1 / 5 y$ r to $1 / 1000 y r$ probability, the latter in the case of large- 
scale life hazard. The Environment Agency carries out detailed inspections on both their own flood protection assets and those of other owners. Inspection frequencies range from every 6 months for high-risk assets, to once every five years for assets where both the flood probability and flood consequences are low. When inspection results are unsatisfactory, in-depth risk assessments may follow. Maintenance actions also depend on the inspection results and include maintenance of grass revetments.

\section{Features of the 2018 drought}

In the Netherlands drought-inspection criteria for levees are usually linked to the so-called summer-season precipitation deficit, because this parameter is readily available (through www.knmi.nl) and a reasonable measure of soil desiccation. The Dutch meteorological office KNMI defines the precipitation deficit as the sum of daily potential reference evaporation (for a moist shortgrass surface according to the Makking method) and daily precipitation, starting from April $1^{\text {st }}$ of each year. Figure 3.1 shows the (NL) country average of the time evolution of the (cumulative) precipitation deficit for the period April-September 2018 (Dutch version provided by KNMI)

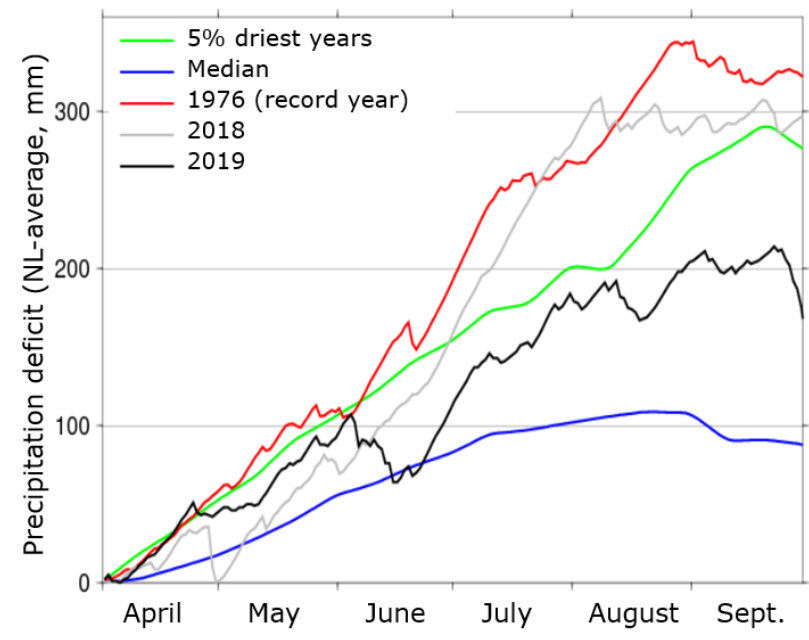

Figure 3.1. Country average of NL precipitation deficit during the summer half years of 2018 (grey) and 2019.

After a wet 2017-2018-winter, the build-up of the 2018 precipitation deficit mainly occurred in the period May-July, and was especially rapid during July. Precipitation deficit peaked at a value three times larger than on average, and $30 \%$ larger than the peak deficit during the 'Wilnis levee failure' summer of 2003, when the deficit was about $234 \mathrm{~mm}$. In fact, only four years (1976, 1947, 1911 and 1921) reached peak deficits in excess of the 2018 value, reaching $320-360 \mathrm{~mm}$. This implies that the 2018 drought had a return time of order 30 years (KNMI, 2018), while the 2003 drought had a return time of about 10 years. Local precipitation deficits can well be $50 \mathrm{~mm}$ below or above these country averages, partly due to several (13) events with heavy local downpours producing 50-120 mm of rain in a day or less. Luckily most downpours occurred in May (before the levees were affected by drought), because such downpours might represent significant loading cases for secondary levees along small water systems.

The extreme 2018 precipitation deficit was linked to:

- Lack of precipitation, with just $37 \mathrm{~mm}$ of rain in the twomonth period of June-July (only $25 \%$ of average and for many locations the driest June + July ever).

- Abundant sunshine: July had an unprecedented sunshine anomaly of $+66 \%$, and May and September each a top-ten anomaly of over $+35 \%$. Normal sunshine amounts are about $200 \mathrm{~h}$ for each of the summer months, 175h for April and 140h for September.

- Exceptional temperatures: The average temperature for the 5-month period April-August was $2.4^{\circ} \mathrm{C}$ above the long-term average temperature of $+14.7^{\circ} \mathrm{C}$ for these months, and $1.3^{\circ} \mathrm{C}$ above the previous highest-recorded temperature for this period. The summer temperature of $+18.9^{\circ} \mathrm{C}$ (June-August) was also record-breaking.

- Mainly due to the sunshine, evaporation in May, July and September was $20-40 \%$ above the long-term average of about $50 \mathrm{~mm}$ for September, and about 90 $\mathrm{mm}$ for each of the months in the period May-August.

There was also an exceptionally long period (midJune-Oct) of low Rhine discharges; see (Bottema et al., 2019) for details. This was followed by yet another two hot summers, although their maximum precipitation deficits $(200-250 \mathrm{~mm})$ were not as extreme, partly because the most intense phase of the latter two droughts was during the spring, rather than the summer.

In England, the meteorological drought conditions in 2018 (based on: RMS, 2018) were not dissimilar from those in the Netherlands. The differences occurred mainly in the details, and during the spring months:

- In April and May, temperatures in the SouthEastern half of England were about $1-2^{\circ} \mathrm{C}$ lower than those in the Netherlands, in June, July and August this difference decreased to about $0.5^{\circ} \mathrm{C}$.

- Precipitation in both February and March was roughly $10-30 \mathrm{~mm}$ higher than in The Netherlands. However, from April to August, precipitation amounts were quite similar to those in The Netherlands, followed by a September which was slightly drier in England.

- The main difference between The Netherlands and England was the amount of sunshine: Even in the South-Eastern half of England, the months of April, May and July each produced about 40h less sunshine than in The Netherlands.

Data on Makkink evaporation in England were not readily available as England uses a different method (Hough \& Jones, 1997), which estimates the actual landscape evaporation rather than a standardised evaporation estimate based on routine meteorological observations only, like the Dutch Makkink method. As a very rough estimate, based on sunshine and evaporation anomalies in The Netherlands, it is expected that for 2018, the April- 
July Makkink evaporation sum will have been in order of $340 \mathrm{~mm}$ in South-Eastern England as compared to a measured sum of about $410 \mathrm{~mm}$ in The Netherlands. This would have resulted in a precipitation deficit of order 240 $\mathrm{mm}$. Actually, this value is similar to the precipitation deficit that was reached during the Dutch peat levee failure near the town of Wilnis, in 2003. Therefore, the 2018 summer is likely to have the potential for producing significant drought effects on levees in the South-Eastern half of England as well.

\section{Failure mechanisms and drought}

In the following, the effects of drought on overall stability, internal erosion and external erosion will be briefly discussed. Some more explanations can be found in (Bottema et al., 2019). The focus in this paper is on levees, although it is noted that clay degradation can cause significant damage to dry infrastructure embankments as well (Eminue, 2018).

\subsection{Overall stability}

Both clay and peat become subject to weathering when they are permanently or even temporarily above the phreatic line. Hence the historical construction practices that favoured high phreatic levels in Dutch peat levees. Obviously, evaporation acts to lower the phreatic line. The important thing to note however, is that deep-rooted (and leafy) vegetation leads to enhanced evaporation, and thus to significant dehydration and lowering of the phreatic level near such vegetation; the level can drop by as much as a metre (EA, 2007; van den Akker et al., 2013).

Peat can significantly shrink and crack when drying out, even more so than clay. Moreover, peat loses weight as it dehydrates, and the air access accompanying drainage will also cause (or enhance) peat oxidation. The latter results in irreversible loss, not only in terms of peat volume, but also in terms of peat strength. Regarding the latter, it must be noted that peat strength significantly depends on the presence of interwoven plant fibres. If these fibres are severed by cracks, or decay because of oxidation, the peat strength significantly decreases, and therefore both its sliding and erosion resistance. The peatvolume change will translate into a crest-level decrease, either temporarily by shrinkage (as might be detected by earth observation similar to Özer et al, 2019) or (especially in the case of oxidation and settlement) permanently. The potential influence of gas formation on stability is often discussed, but never researched.

Drainage of peat can also result in significant weight loss. In some cases, a decrease of peat weight can reduce effective stresses to the extent that horizontal sliding of a complete levee segment occurs, like in the Wilnis case (Van Baars, 2005). This is especially relevant if water pressures in an underlying aquifer become or remain high.

For levees (partly) consisting of clay, drought can cause desiccation fissuring and cracking of the top layer. These fissures and cracks extend into the levee and can be up to $1 \mathrm{~m}$ deep, in some cases perhaps even more. When the fissures interconnect, a rubble-like structure may result, with significantly increased top-layer permeability. If the drought is soon followed by a flood or storm surge, the increased permeability can potentially lead to the landward collapse of the inner slope by repeated uplifting of the rubble-like clay blocks, especially but not exclusively if wave overtopping occurs (Dyer et al, 2007). In the case of wave overtopping, the phenomenon can be linked to shallow slope instability as a result of overtopping infiltration. Without overtopping, there some parallels with micro-instability phenomena for sand (Bottema et al., 2019).

With high outside water levels (and perhaps even with extreme rainfall only), the fissures and cracks can also affect the overall stability of the levee, as the increased toplayer porosity increases the risk of the levee becoming saturated with water. If fissures become sufficiently deep, even leakage through the levee and internal erosion may occur. When the levee is seriously overtopped, both shallow slope instability and uplift of clay blocks affect erosion resistance and thus increase the erosion of the landward (inner) levee slope. Whether cracks along the levee crest are critical or not is not fully clear. In (EA, 2007) they are assumed to be caused by imperfect construction rather than drought, but Dutch drought inspections during the last summers saw several examples of long cracks popping up along the slopes and crests of levees.

The above risks are largest when a levee is permanently loaded (like canal levees) or loaded before it has been able to recover from a drought. When a wetter period occurs after the drought, the clay fissures can in some cases close within days (EA, 2007), but they can also turn out to be much more persistent (see Section 5).

For a peat top layer the same mechanism may be relevant. However, the potential failure risk for peat levees is larger because the formation of drought cracks in peat is less reversible than for clay, even when there is a wet period between the drought and the actual levee-loading event. Therefore, it is strongly recommended to repair the fissures before high water levels are to be expected.

\subsection{Internal erosion}

Four types of internal erosion are defined in literature (CIRIA, 2013):

- Backward piping erosion;

- Concentrated leak erosion;

- Suffusion;

- Contact erosion.

In the Netherlands the main reason for concern amongst these mechanisms is backward piping erosion, This applies especially for clay levees on top of a sandy sub-soil, and along major rivers, even only few actual levees failures can be directly linked to internal erosion (Van Baars and Van Kempen, 2009). In England underseepage and backward piping erosion might be 
somewhat less critical than in the Netherlands, but concentrated leak erosion along hard elements and hard structures can still be a reason for concern.

The actual onset of internal erosion requires:

- An entry point or entry zone at the water side of a levee;

- An exit point at the landward levee side;

- Sufficient head across the levee to cause uplift of a top layer (if present), followed by heave instability of the sand, and finally followed by backward piping erosion, ultimately leading to hydraulic short-circuiting between the river and the internal erosion pipe.

Drought can influence or trigger internal erosion on the following ways:

- Drought causes shrinkage and cracking of clay and peat, which can lead to new (unfavourable) entry or exit points, or to new seepage paths, especially along hard structures and transitions;

- Near weirs and locks, drought can lower downstream river levels to such an extent that exceptionally large heads develop across the weir (or lock);

- With extremely low river levels, the slope of the phreatic line within a levee can reverse, and entry points at the river side can even become exit points.

The latter is unlikely to cause direct failure, but still it points at weaknesses of the levee and its subsoil.

\subsection{External erosion}

Many Dutch and English levees are covered with grass revetments, especially their crest and inner slope. The grass cover and especially its root system provide significant strength to resist erosion due to overtopping. This also applies to the clay layers which are often present below (except of course for pure sand levees).

Drought has the following impact on external erosion: - Especially on sand levees, but also on other types of levee, it deteriorates the quality of the grass and its root system, decreasing erosion resistance. Moreover, relatively deep-rooted weeds may better survive dry spells, and take over when there is too much damage to the grass root system;

- In clay and peat, it causes desiccation fissuring and/or larger cracks. Near such cracks, the root system will be ruptured and the revetment will degrade to loose grass lumps rather than a continuous closed-sod cover;

- The underlying layer will weather, crack and in the case of clay ultimately degrade to rubble (Dyer et al, 2007), significantly reducing its erosion resistance;

- The weathered clay leads to increased infiltration capacity, which increases the risk of overtopping erosion and slope instability acting together.

Trees and transitions are an extra reason for concern. Trees not only have relatively deep root systems which can extract large quantities of water from the soil, but they also inhibit full development of grass revetments in their vicinity. Due to hydrodynamic effects, they also act as a focal point for overtopping erosion. Transitions do not extract water from the levee, but otherwise their impact can be quite similar to that of trees, all the more so since clay shrinkage often leads to cracks along such transitions.

\section{Observed drought impact on levees}

\subsection{Observations in The Netherlands}

In the following, some observations of drought impact on Dutch flood defences are summarised, with focus on peat levees, clay levees with grass revetments, and on other phenomena and other types of flood defence. The focus will be on the drought of 2018, but some observations from 2019 will be included as well.

It should be noted that the results are not based on indepth quantitative research, but rather on summaries (https://handreikinggrasbekleding.nl ; Van Haastrecht, 2019; STOWA, 2019;) of fairly qualitative levee inspectors' feedback. Unfortunately, only little information is given on drought crack dimensions, although the publications given above mention several observations reporting cracks that were deeper than $0.5 \mathrm{~m}$. Especially for secondary (peat) levees, drought-damage induced seepage is also reported on some occasions, but again it is unfortunate that no details are given. Finally, it is important to note that drought impact appears to be fairly site-specific, so that the results reported below rather are indications of trends than hard trends that would apply to all cases.

One of the most striking examples of drought impact on peat levees is shown on a You Tube video called "droogteinpectie" (https://youtu.be/JvSb19ck4M8 ; Bosma, pers. comm.).

The video shows a small clay levee and a lower meadow on a peat subsoil (for which it was classified as peat levee). Both are crossed by multiple cracks, some of which over 10 meters in length, one meter in depth, with widths up to $10 \mathrm{~cm}$. Probably, a combination of factors led to this massive crack development. Firstly, the type of clay was sensitive to shrinkage/cracking, and perhaps the clay had been too wet during construction. Another key factor was that the regular grazing by sheep had turned into overgrazing, exposing the soil. Finally, an abundance of mice and their burrows contributed to the desiccation of the clay (and the underlying peat, which can enhance its oxidation and result in peat compaction). One year later, the grass still had trouble recovering, while crack damage had hardly reduced (STOWA, 2019). The main reason for not repairing the cracks was linked to the limited amount of assets protected by the levee.

Two additional examples of large cracks are given in Figure 5.1. Figure 5.1a shows a longitudinal crack on a Rijkswaterstaat clay levee with nearby trees (covered with dry tree leafs due to the drought), along the Amsterdam Rhine Canal near the village of Ravenswaaij. Maximum values of crack width and crack depth were reported to be 
as large as $5-10 \mathrm{~cm}$ and 1 metre respectively (Lievens, 2019). Figure 5.1b shows longitudinal cracks on a small levee by March 2019, half a year after the drought, in the same Frisian region where the aforementioned video was taken. The pictures illustrate that the longitudinal cracks can become quite large, and (in the latter case) can turn out to be quite persistent. In fact, many levee owners have observed one or several cases of such longitudinal cracking (Van Haastrecht, 2019).
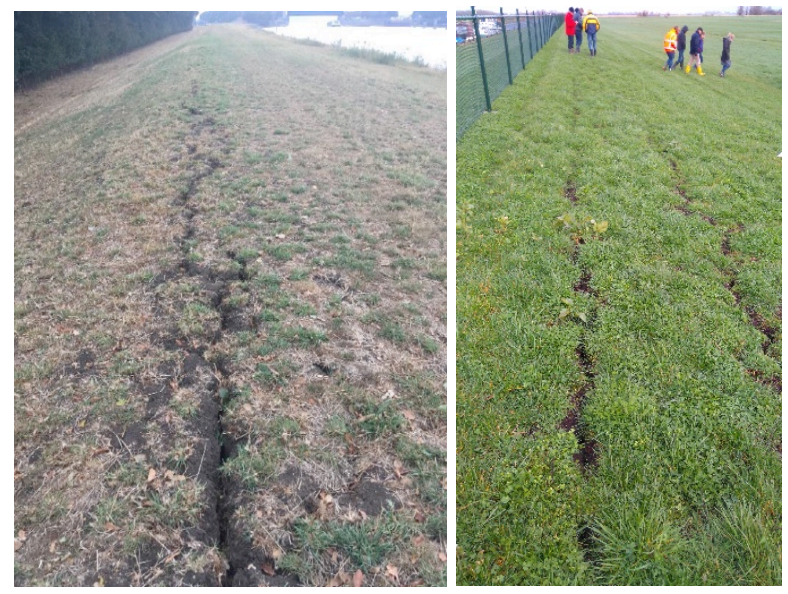

Figure 5.1. Longitudinal cracks as observed at two different secondary levees, during and well after the drought. Left: clay levee along Amsterdam Rhine Canal, near the village of

Ravenswaaij (Aug 2018; kindly provided by Mr. A Lievens, RWS MN) Right: Right photo: Cracks on a small levee in a peaty area in Frisia (March 2019; photograph by 1st author).

Although the drought impact reports (Van Haastrecht, 2019; STOWA, 2019) put some emphasis on drought effects on secondary levees, this does not imply that drought impact has not been a concern for primary levees. In fact, deterioration of grass revetments and the occurrence of clay cracks was observed on numerous primary levees during the summer of 2018, and sometimes even well into the next year 2019. Yet there were marked differences, with some levees being quite strongly affected, and other levees much less so. This also applies to the recovery from drought damage, with many levees recovering quite quickly, and some levees having persistent cracks and grass revetment damage (Haastrecht, 2019).

The levee 'Oostvaardersdijk' to the southwest of the town of Lelystad presents a nice example of grass and clay deterioration where recovery was slow. See also Figure 5.2. This levee must soon be significantly raised to meet the new, more stringent, safety standards. Therefore it is essential to have a closed and erosion-resistant grass revetment on its crest and inner slope. In recent years, an abundant population of mice had already caused some minor damage. During the 2018 drought, an unlucky timing of the grass cutting contributed to the drought damage. Generally, grass cutting takes place in June/July (amongst others because of the bird-breeding season), but this year, this timing coincided with the most intense phase of the drought. After the July 2018 grass cutting, bare patches developed of several decimetres or even metres in size. Significant clay cracking occurred as well, exacerbated by the tracks and burrows of the mice. After an August with average rainfall, only superficial recovery had occurred. Seven months later, by the end of March 2019 , the was still only partial recovery of the grass and the clay, and during the 2019 summer even some longitudinal cracks along the upper inner slope and levee crest were observed. Real recovery only set in after the wet autumn of 2019, more than a year after the 2018 drought. Meanwhile, grass had been replaced by (less erosionresistant) weeds on several of the drought-damaged bare spots. The cracks in 2019 appeared to be less abundant than during the 2018 drought, but the burrowing damage had remained and perhaps even extended, to the extent that locally, the slopes had become uneven.
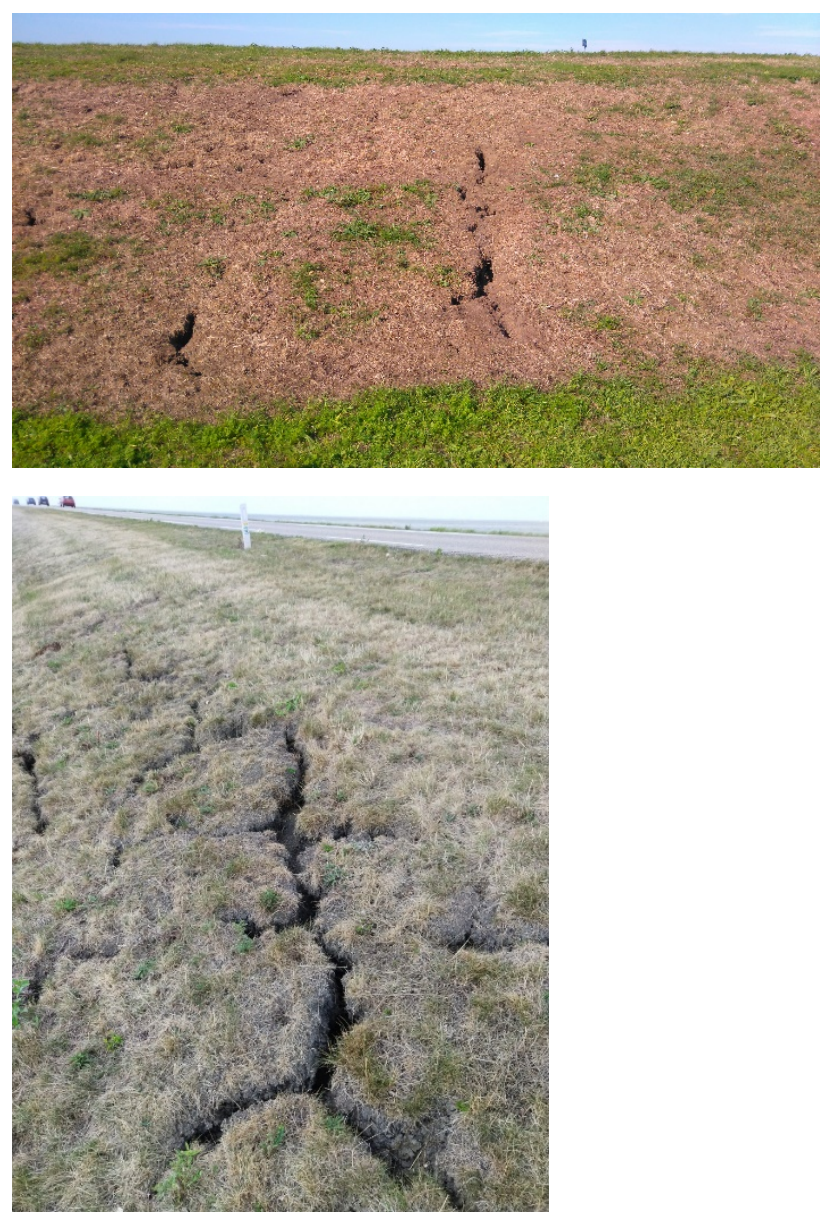

Figure 5.2. Drought damage on a primary levee (Oostvaardersdijk, $10 \mathrm{~km} \mathrm{SW}$ of the Dutch town of Lelystad). Top: 26 Sept 2018, 7 weeks after the drought; Bottom: 12 Aug 2019, one year later Photographs by the first author.

This example suggests that a combination of drought, animal burrowing and unlucky timing of grass cutting can cause significant damage to grass and clay revetments, which can even last into the next year (while spanning the storm season in between).

The Oostvaardersdijk case and especially the photographs of Figure 5.2 serve just as an example for one specific location. Many other experiences and good practices regarding drought mitigation and grass revetment 
management in general are shared on the platform https://handreikinggrasbekleding.nl. Some key lessons and experiences are:

1. Especially sand core levees covered with clay (like the Oostvaardersdijk) are vulnerable to drought damage. On too 'heavy' clay (prone to shrinkage and hard when drying), grass is also vulnerable because grass root systems have trouble penetrating such hard clays.

2. Natural grass covers are less prone to drought than recently seeded grass covers

3. Overgrazing and cutting the grass (too short) during drought is best avoided

4. Large cracks or cracks with deformations are commonly repaired using fresh clay; how fast and to which extent cracks recover is largely unknown.

5. Some levee managers (but not all) spray/irrigate their (peat) levees during drought

6. Some dried-out grass revetments on levees were damaged by fire.

7. Grass revetments can recover quite quickly from drought as long as their root system is largely undamaged. Large bare patches are a sign that root systems (which should provide erosion resistance) have died. The bare patches need to be seeded again, preferably in September, to re-establish the grass root systems, and to prevent the wrong type of weeds taking over.

Trees can also have a negative impact, both on the grass and on the clay (Van den Akker, 2013).

With respect to other phenomena, and other flood defences types, the following observations are worth mentioning:

- In a few cases, drought-induced shrinkage and deformation of (material of) levees led to some deformation of pipes and cables, or to seepage along those objects. Such seepage can be the precursor to concentrated leak erosion.

- In some cases, cracks and openings appeared along hard-soft (concrete-clay) transitions, which had to be repaired. For example at the Hollandsche IJssel storm surge barrier.

- Near a levee along the river IJssel, reversed internal erosion occurred, with sand boils in the river rather than on the landward side of the levee. This was linked to extremely low river levels. See also Section 4.2.

- Underseepage was observed at the weir 'De Haandrik' in the river Vecht (East of NL). This was linked to exceptionally large water head, as the weir stored water upstream, while the downstream level was very low. Big bags were placed directly downstream of the weir to provide an intermediate buffer to reduce the head.

\subsection{Observations in England}

In England, the Wilnis-type of peat levee failure (see Section 1) is less likely and therefore drought is rather associated with levee deterioration. During the 2018 drought, three main issues emerged regarding English FRM assets:

1. Shrinkage cracks and settlement of clay embankments

2. Deterioration of grass revetments

3. Issues with hydraulic structures.

Details are given in (Welton, 2018). Unfortunately, information about recovery from the drought impact is not readily available.

Regarding the first issue, no significant foundation shrinkage or embankment settlement was reported, not even in areas with peaty sub-soils in East England. There was one exception: a case where a concrete flood wall started to move because of shrinkage beneath the foundation.

On the other hand, clay cracking occurred quite frequently, albeit without significant effects on structural integrity. Occasionally, crack depths extended to $60 \mathrm{~cm}$ in depth, in a few cases even to 1 metre in depth (and a width up to $4 \mathrm{~cm}$ ). After the rain of August 2018, there was some evidence of self-healing of the cracks in some areas, but not in all cases. The cracking of clay top-layers was not limited to levees: annual inspections of some reservoir embankments also revealed cracks up to $60 \mathrm{~cm}$ depth.

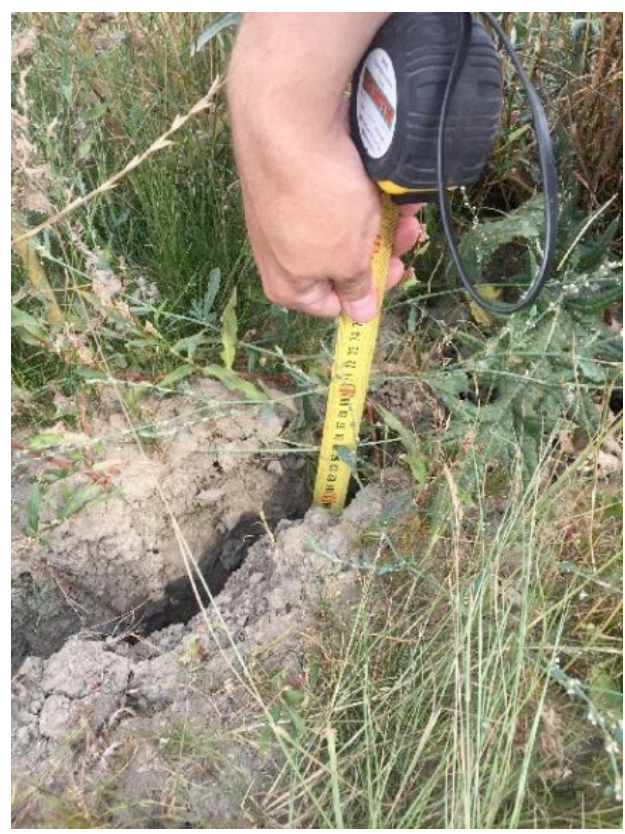

Figure 5.3. $60 \mathrm{~mm}$ deep crack in an embankment (source: Welton, 2018).

The second main issue was the deterioration of grass revetments that should provide erosion resistance. Many grass revetments were affected by drought, and by July, grass cover often had become sparse. Yet the root matrix usually remained intact. After the rains of August, many grass revetments started recovering. In some of the (drier) areas, the recovery did not take off that well. Also, deeper rooting broadleaf species had often taken over when the grass cover had been too much affected by the drought. For reservoir embankments, grass deterioration was less of an issue since only some offline reservoirs depend on grass revetments for erosion protection. 
The third issue is not specifically related to levees but rather to other FRM and water management assets: due to the low water levels caused by the drought, many moveable hydraulic structures could not be operated or exercised for long periods.

Besides these observations from practice, it is also relevant to mention some findings (Eminue, 2018) from a full-scale research embankment of clay that were obtained in the years before the 2018 drought:

- Cracking patterns for sludge and clay were found to be somewhat different, as were full-scale and laboratory cracking patterns. Hence, caution is needed when applying literature findings to in-situ cracking of clay embankments;

- The in-situ observed cracks tended to be quasi-linear, but with random orientation and fairly random length. On the other hand, crack width appeared to correlate well with crack depth;

- Horizontal sub-surface cracks were also observed, but unfortunately crack connectivity was not investigated;

- Cracks tended to develop quickly within quite a narrow soil-water content range, just below the plastic limit of the clay;

- Sun-exposed (south-facing) slopes and highly plastic and/or poorly compacted soil all tended to favour clay cracking;

- Many cracks tended to close upon rewetting. However, the overall picture seems to be that repeated dry-wet cycles lead to progressive clay degradation through pre-existing and new cracks. This also points at a limitation of Ominue's research: crack depths observed in the first year(s) after construction may underestimate the final crack depth;

- Mice burrows tended to widen cracks and were quite common;

- Vegetation tends to extract moisture from the root zone, which is especially an issue with deep-rooting vegetation. Still, grass revetments tend to be beneficial by reducing clay cracking. This can be attributed to both mechanical resistance and shading of the soil; direct insolation greatly contributes to moisture loss of bare soils.

\subsection{Comparison of NL and UK observations.}

By and large, the drought impact on Dutch and English levees was quite similar. In fact, many of the observations from Dutch levee inspections are consistent with Ominue's (2018) findings obtained from the UK research embankment; especially the findings described in the last four bullet items of section 5.2 above.

However, in The Netherlands extreme drought impact appeared to occur more often than in England. The following factors may play a role in this:

- The fact that the meteorological drought was more intense than in England (Section 2)
- The fact that the Netherlands not only have peaty subsoils, but also peaty levees, favouring extreme cracking, to the point that even seepage occurred.

- Soil compaction in the Netherlands, leading to cracks at hard-soft transitions, and to deformations of pipes and cables embedded in levees. It would be interesting to have a closer look at this difference between The Netherlands and England, considering the thickness of peaty layers in each country.

Another remarkable difference is that for England, Welton (2018) did not report the extreme variability in drought effects that was reported in The Netherlands. This implies that statistics on drought effects will probably be quite sensitive to the way in which field observations are reported.

\section{Drought management}

Since the 2003 peat levee failure near Wilnis, all Dutch levee managers (the 21 Dutch Water Boards as well as Rijkswaterstaat) have a protocol for intensified inspections and dedicated management interventions during drought. Most of these protocols are fitted to local conditions and the properties of the levee portfolio of each levee manager. As a result, there are significant differences with respect to drought inspection criteria between each of these organisations.

However, what all drought protocols for Dutch levees have in common, is that they are risk-based in some way. As a result, intensified visual inspections are first applied to high-risk and/or drought-prone levees. The observed drought effects, as described in the previous section, clearly justify the need for such intensified inspections. In some cases, most or all of the levee portfolio gets an initial inspection (for reference) first. As the drought intensifies and the precipitation deficit increases to exceed subsequent thresholds, inspections are intensified up to once every 1-2 weeks, and also extended to levees with lower risk and lower vulnerability to drought. For the most vulnerable levees, intensified inspection may already start with precipitation deficits of $100 \mathrm{~mm}$ (Van Haastrecht, 2019). This may occur by the end of May in dry years, and around August in regular years. Intensified inspections for less vulnerable levees will sometimes not be initiated until precipitation deficits exceed values of 200-275 mm (which occurs only in dry years and not before July). See (Van Haastrecht, 2019; STOWA, 2019) for details. In the case of the 2018 drought, river levels dropped so low during the autumn, that Rijkswaterstaat issued special warnings to levee managers, informing them about the possibility that in that specific situation, clay cracks may become deeper than in previous droughts.

Interventions seem to be most effective in the design and construction levee life-cycle phase, since in many cases, desiccation cracking is caused or exacerbated by placing clay (or peat) which is still too wet, too plastic, not properly compacted, or - in the case of clay - with too much organic content. In current construction practice, the 
lessons should normally be accounted for, but this is not always the case for levees which have not been recently constructed or modified.

For existing levees the following measures are commonly taken to prevent excessive and/or deep cracking:

- Clay capping: In recent years, this measure has been applied to most peat levees (Van Haastrecht, 2019); the clay clap reduces desiccation and subsequent cracking, oxygen access, and peat oxidation and shrinkage due to drying.

- Vegetation management: Preventing and/or removing deep-rooted weeds and woody vegetation is essential to avoid deep cracking and weathering, which in the case of woody vegetation can extend a few metres deep. Regular grass cutting or grazing is recommended (similar to UK practices, as mentioned in EA, 2007). However, the 2018 experiences demonstrate that exaggerated grass cutting and overgrazing can actually accelerate desiccation of levees. Recent experimental research (Ominue, 2018) also suggests that soil desiccation tends to increase as vegetation cover decreases and more bare soil is exposed to insolation.

- Moisturising/Spraying the levee: This measure is applied by some Water Boards but not all. It is important to spray before water-repellent behaviour and cracking occurs, and then to keep up with evaporation. That is quite a challenge, because the large volumes of water required must be provided gradually, rather than 'dumped' on the levee.

Once cracks have developed, cracks can either be filled with swelling clay (bentonite) or replaced with new soil/clay. Both solutions have their limitations. The benefit of filling cracks is that it reduces further desiccation during drought, and reduces unwanted water infiltration during intense rain and overtopping. On the other hand, filling cracks tends to be limited to the top layers, which actually may inhibit closure of these cracks at deeper levels. Replacing cracked soil with new soil/clay sounds promising, but implies replacing the grass revetment as well, which may then require a few years to get full erosion resistance.

In England, there are no known cases of droughtinduced levee failures. Perhaps for that reason, there appear to be no drought protocols for levees in England, at least not in the present English drought response framework (EA, 2017). Despite this, the English levee managers made a quick and adequate response to the 2018 summer drought.

The actions taken in England were quite similar to those taken in The Netherlands:

- Intensified monitoring of the situation;

- Intensified contacts between national and regional government bodies (between 'National Operations' and 'Areas');
- Modified maintenance activities

- Suspended grass cutting

- Remedial action in the case of deep cracks

Active wetting of English levees was contemplated, but not deemed necessary since the levees did not consist of peat.

A final action worth mentioning is that the existing cooperation between England (Environment Agency) and The Netherlands (Rijkswaterstaat) on asset management, knowledge management, water management, FRM and incident management was used to quickly establish exchanges about experiences on managing the 2018 drought impact on levees, and on knowledge gaps on this issue. Through these exchanges, the Dutch were made more aware of the potential of seasonal forecasts, and the English about the drought-related risks of peat levees.

\section{Conclusions and recommendations}

Drought can be a significant risk factor to levees, even though only a small percentage of levee failures can be directly attributed to drought. An example of the latter is the Wilnis levee failure during the summer drought of 2003, caused by horizontal sliding after weight loss of the peat and hydraulic short-circuiting. For clay revetments, drought will compromise both the impermeability and erosion resistance; in fact drought-induced cracks can even become deep enough to become relevant for dams. Grass revetments are also vulnerable to drought, especially for clay-topped sand levees.

Since the 2003 Wilnis failure, inspection, maintenance and safety management of secondary levees in the Netherlands has markedly improved. Perhaps for that reason, no (near) failures of levees occurred during the even more extreme drought of 2018. Still several signs of strength reduction were observed, such as deep cracks in peat and clay, deteriorated grass revetments, and a few cases of reversed internal erosion, and of underseepage at sluice gates. By and large, similar effects occurred in England.

Our recommendations are as follows:

1. Drought can be a significant deterioration and risk factor for levees (and quite likely also for earthen dams). Intensified inspections and remedial actions during drought are recommended. The development and use of tools to map the vulnerability of FRM assets to drought impact is also recommended, together with the development of predictive tools. In fact the Environment Agency is already working with the British Geological Survey on these latter issues. Both historical research (Derksen, 2019) and remote sensing may also help to identify locations with potential levee or sub-soil vulnerabilities.

2. In order to get a reliable national overview of drought impact on levees, it is important to carefully design the procedures for drought inspections and their reporting. This is critical to make sure the right 
features are being reported about, and that no overreporting or under-reporting of certain features occurs, either in the reporting itself, or through the subsequent analyses. This may be especially relevant for the Netherlands with its roughly 20 decentralized water boards, as opposed to England where the Environment Agency has a more central role.

3. In practice, the depth to which weathering and cracking extends for clay and for peat is an important knowledge gap. Cracking properties (horizontal size, connectivity, occurrence, development) are important as well. A crack register would be useful but perhaps is not feasible given the extreme effort needed to measure up all these features in a levee portfolio. Especially for estimating the depth and connectivity of cracks, it is important to develop suitable monitoring techniques since visual inspections seem to be less suitable for this.

4. In a laboratory or agricultural context there has been a reasonable amount of research, but it is not always directly applicable to embankments (Eminue, 2018) and is mainly limited to clay. Some research on drought effects on levees has been published, but it appears to be somewhat scattered. Therefore, it is recommended to internationally share experiences related to drought effects on levees and dams, and their remediation.

5. Additional research appears to be useful for some topics, for example the effects of animal burrowing the effects of woody vegetation on drought damage to levees, the effect of repeated dry-wet cycles on crack healing, crack reoccurrence and progressive degradation of clay and peat (especially in deeper layers inaccessible to visual inspection), drought monitoring by remote sensing (Özer et al, 2019), the translation of small-scale laboratory tests to field conditions, and the drought and erosion resistance of grass revetments.

6. Observational and experimental studies remain highly useful, but a complementary track of modelling is equally important. Integrated soil-water, crackdevelopment and geotechnical modelling is challenging and rests on several assumptions, but efforts are nevertheless being undertaken (Jamalinia et al., 2020). A useful insight is that crack development appears to occurs quite rapidly within a narrow soil water content range, just below the plastic limit of the clay (Ominue, 2018). The modelling of the effect of existing cracks seems to be reasonably established, although the modelling of pore water pressures is critical given their importance (Wang et al., 2011).

7. Also, it is recommended to verify whether current design and management practices for temperature climates still hold, or whether the depth of clay weathering is greater than currently assumed (roughly speaking: $>1 \mathrm{~m}$ ), both at present and under climate change.
8. The English experiences point at some interesting developments in seasonal weather forecasting, as positive sea surface temperature anomalies between $30-45^{\circ} \mathrm{N}$ and $40-80^{\circ} \mathrm{W}$ (and negative anomalies elsewhere; Dunstone et al, 2019; McCarthy et al., 2019) might be an indicator for dry summers in North(-West)ern Europe. For The Netherlands, it may also be interesting to consider the different drought definitions as used in England (i.e. environmental meteorological, environmental or agricultural) and the drought indicators that are associated with these definitions.

9. Some innovations may also be of interest, like:

a. Investigate the potential of lime-treated soils to reduce resistance against external and internal erosion of levees and dams, and reduce swelling/shrinkage effects as well as the vulnerability to drought (EA, 2007).

b. Consider a three-stage approach of risk-based drought inspections of levees (Utili et al., 2014). First monitor open-access meteorological data, then do visual inspections, as a final and new step: carry out a walk-over with geophysical monitoring in the case of significant risk and/or degradation.

c. The use of electrical resistance tomography (ERT) and similar techniques to map soil properties like water content. These techniques suggest that in the case of weathered embankments, may well infiltrate beyond 1 metre of depth, see for example (Stirling et al., 2018).

\section{Acknowledgements}

This paper has greatly benefited from the contributions of several people who shared experiences, provided data, figures and photographs, and gave suggestions regarding the text.

For sharing information and photographs, we especially wish to thank Mr. Jaap Bronsveld, Mr. Niek Bosma and Mr. Wijnand Evers of the Water Boards of Rivierenland, Fryslân and Drents-Overijsselse-Delta respectively, and Mr. Arthur Lievens of Rijkswaterstaat Midden Nederland.

\section{References}

1. Bottema, M., Vonk, B., Janssen, H., Van Waveren, H., 2019: Mitigating drought risk for levees, Proc. $11^{\text {th }}$ EURCOLD Symposium, 2-4 Oct 2019, Chania, Greece.

2. Boussafir, Y.\& Tourment, R. \& Veylon G. \& Durand E. \& Sauassaye L. \& Reiffsteck P. 2019: Evaluer l'impact du veillissement des digues sur les mécanismes et scénario's de rupture (Evaluating levee-ageing impact on failure mechanisms and scenario's ; in French), Proceedings Digues Maritimes 
et Fluviales de Protection contre les Submersions, March 2019, Aix-en-Provence, France

3. CIRIA, 2013: The International Levee Handbook, CIRIA publication C731, CIRIA, London, UK

4. Den Haan, E. \& Termaat, R. \& Edil, T.B. 1994: Proceedings of the International Workshop on Advances in Understanding and Modelling the Mechanical Behaviour of Peat, Balkema Publ., Rotterdam, 428 p.

5. Derksen, M., 2019: Historisch onderzoek veenkaden, stap 2 (historical research peat levees), Royal Haskoning DHV Report T\&BF4316R002D01, for STOWA.

6. Dunstone, N. \& Smith D. \& Hardiman S. \& Eade R. \& Gordon M. \& Hermanson L. \& Kay, G. and Scaife A., 2019, Skilful real-time seasonal forecasts of the dry Northern European Summer 2018, Geophys. Res. Letters DOI 10.1029/2019GL084659

7. Dyer, M. \& Utili, S. \& Zielinski, M., 2007: The influence of dessication fine fissuring on the stability of flood embankments, Strathclyde University, FRMRC Research Report UR11, www.floodrisk.org.uk.

8. EA, 2007: Earth Embankment Fissuring Manual, UK Environment Agency, R\&D technical Report W41

9. EA, 2017, Drought response: our framework for England, Environment Agency, https://assets.publishing.service.gov.uk/government/ uploads/system/uploads/attachment data/file/625006 /LIT 10104.pdf

10. Eminue, O.O., 2018, Environmental and material controls in desiccation cracking in engineered clay embankments, PhD Thesis, Newcastle University, UK, https://theses.ncl.ac.uk/jspui/handle/10443/4101

11. EURCOLD, 2019: European and US levees and flood defences, Characteristics, Risks and Governance, Work-ing Group on Levees and Flood Defences of the ICOLD European Club, DOI 10.24346/cfbr_eurcold2018

12. Hough, M. \& Jones R., 1997: The United Kingdom Meteorological Office rainfall and evaporation calculation system: MORECS version 2.0-an overview. Hydrology and Earth System Sciences Discussions, European Geosciences Union, 1997, 1 (2), pp.227-239.

13. Jamalinia, E., Vardon, Ph, Steele-Dunne, S., The impact of evaporation induced cracks and precipitation on temporal slope stability, Computers and Geotechnics, 122 [103506] DOI 10.1016/j.compgeo.2020.103506

14. KNMI, 2018: De droogte van 2018 - een analyse op basis van het potentieel neerslagtekort (KNMI drought evaluation, in Dutch), KNMI report, www.knmi.nl

15. Lievens, A., 2019: personal communication. A. Lievens, Rijkswaterstaat MN, 2 Dec 2019.

16. McCarthy, M. \& Christidis, N. \& Dunstone N \& Fereday D. \& Kay, G. \& Klein-Tank, A. \& Lowe, J.
\& Petch J. \& Scaife, A. \& Stott, P., 2019, Drivers of the UK summer heat wave of 2018, Weather, 74-11, p. 390-396

17. Morris, P.H. \& Graham, J. \& Williams, D.J., 1992: Cracking in drying soils, Can. Geotech J. 29: 263-277

18. Özer, I.E. \& Rikkert, S.J. \& Van Leijen, F.J. \& Jonkman, S.N. \& Hanssen, R.F., 2019: Sub-seasonal Levee deformation observed using satellite radar interferometry to enhance flood protection, Nature Scient. Reports, 9: 2646

19. RMS, 2018, (monthly) Weather Log, Weather 74-1 75-2, Royal Meteorological Society

20. Slomp, R., Knoeff, H., Bizzarri, A., Bottema, M., De Vries, W., 2016: Probabilistic Flood Defence Assessment Tools, Proc. FloodRisk2016, E3S Web of Conf. 7, 03015.

21. Stirling, R.A., Glendinning, S., Davie, C.T., HenJones, R.M. Hughes, P.N, 2018, The behaviour and influence of desiccation cracking on a full-scale vegetated infrastructure embankment, Proc. $7^{\text {th }}$ Int. Conf. on Unsaturated Soils, Hong Kong.

22. STOWA, 2005: Naar een draaiboek voor droogtegevoelige kaden (towards an action plan for droughtprone levees, in Dutch, STOWA-report 2005-03, www.stowa.nl

23. STOWA, 2019, Acties Waterkeringen Droogte (drought actions flood defences), Memo, $17 \mathrm{Sept}$ 2019, $\quad$ https://waterweren.org/wpcontent/uploads/Acties-Waterkeringen-Droogteversie-17-september-2019.pdf

24. Utili S., \& Castellanza, R.\& Galli, A. \& Sentenac, P., 2015: Novel approach for health monitoring of earthen embankments, J. Geotech. Geoenvir. Eng. 114-3: 04014111 (https://ascelibrary.org/doi/full/10.1061/\%28ASCE\% 29GT.1943-5606.0001215 )

25. Vahefird, F. \& Robinson, J.D. \& A Aghakouchak, A., 2016: Can protracted drought undermine the structural integrity of California's earthen levees, J Geotech. Geoenviron. Eng. 142-6

26. Van Baars, S. 2005: The horizontal failure mechanism of the Wilnis peat dyke, Géotechnique 55(4): 319-323

27. Van Baars, S. \& Van Kempen, I.M., 2009: The causes and mechanisms of historical dike failures in the Nether-lands, E-Water publication, EWA, ISSN 1994-8549

28. Van den Akker, J.J.A. \& Hendriks R.F.A. \& Frissel, J.Y. \& Oostindië, K. \& Wesseling J.G., 2013: Gedrag van verdroogde kades (behaviour of dried-out levees; in Dutch), WUR/Alterra report 2473, October 2013, ISBN 1566-7197

29. Van Haastrecht, B., 2019: Evaluatie droge zomer 2018 waterkeringen (evaluation dry summer 2018 \& levees, in Dutch), STOWA-report 2019-10, www.stowa.nl

30. Vonk, B.F., 1994: Some aspects of the engineering practice regarding peat in small polder dikes, Proc. Int. Workshop on Advances in Understanding and 
Modelling the Mechanical Behaviour of Peat, Balkema Publ: 389-401

31. Wang, Z.F., Li, J.H., Zhang, L.M., 2011 Influence of cracks on the stability of a cracked slope, Proc. $5^{\text {th }}$ Asia-Pacific Conf. on Unsaturated Soils, p721-728

32. Welton, Ph., 2018, Prolonged Dry Weather - Impact on Environment Agency Assets, internal document, 11 Sept 2018, Environment Agency, England. 